STUDIA IURIDICA TORUNIENSIA

PRZEMIANY POLSKIEGO PRAWA, TOM DRUGI

pod red. Ewy Kustry, Toruń 2002

Kinga Bączük

\title{
Zasada swobody umów w prawie polskim
}

\section{Uwagi wstepne}

Swoboda umów jest jedną $z$ najbardziej doniosłych zasad w prawie zobowiązań. Ksztalt nadany jej norma art. $353^{\prime}$ k.c. jest wynikiem przemian, jakie następowały począwszy od wejścia w życie kodeksu zobowiązań (art. 55 k.z.), poprzez okres obowiązywania przepisów ogólnych prawa cywilnego oraz kodeksu cywilnego do noweli z 28 lipca 1990 r., kiedy żaden przepis nie wyrażał tej zasady bezpośrednio. Kodeksowe ujęcie zasady swobody unów w rany obowiązującej normy prawnej nie oznacza jednakże zahamowania jej ewolucji. Zasada ta nadal się rozwija i jest kształtowana przez literaturę i orzecznictwo.

\section{Zasada swobody umów na tle art. 55 kodeksu zobowiązań}

Doniosłość jurydyczna normy art. 55 k.z. z 1933 l.' polegała na stanowczym, tj. bezpośrednim wprowadzeniu do polskiego ustawodawstwa cywilnego zasady wolności umów ${ }^{2}$. Jednocześnie przepis ten uważany był za najbardziej wyraźną i bezpośrednią formułę proklamująca ideę wolności kontraktowej na tle innych ustawodawstw europejskich recypujących liberalne wzoice wielkich kodyfikacji zachodnioeropejskich przetomu XIX i XX w., w szczególności zaś kodeksu Napoleona oraz Bürgerlichen Gesetzbuch ${ }^{3}$.

1 Rozporzadzenie Prezydenta RP z 27 X 1933 r. - Kodeks zobowiazań, Dz.U. Nr 82, poz. 589; sprost. Dz.U. z 1934 l: Nr 54, poz. 492.

2 R. Longchamps de Berier w: Uzasadnienie projeklu kodeksu zobowiqzań, t. 1, Warszawa 1936, s. 72 .

${ }^{3}$ Więcej na ten temat zob. S. Buczkowski, Zasada wolnosici umów, Państwo i Prawo 1961 , z. 3, s. 432 . 
Ujęcie art. 55 k.z. zbliżało się do modelowego w tym względzie art. 1134 ust. 1 kodeksu Napoleona. Inna była jedynie (z punktu widzenia techniki legislacyjnej) konstrukcja samej normy. Ustawodawca polski bowiem, przyznając stronom generalna kompetencje ${ }^{\dagger}$ do swobodnego ksztaltowania treści (i celu) zawieranych w obrocic unów, jednecześnie zakreślit ramy, $w$ których swoboda ta była dopuszczalna. Ustanowione normą art. $55 \mathrm{k} . z$. ograniczenia były jednak identyczne z kryteriani wyznaczonymi przez ustawodawce francuskiego $w$ art. 6 kodeksu Napoleona $i$ odnosily się do ustawy, klauzuli generalnej porządku publicznego oraz dobrych obyczajów. Ogólna konstrukcja jurydyczna zasady autonomii kontraktowej pozostala więc nienaruszona, przy uwzględuieniu odmienności pojawiających się na tle interpretacji pojęc objętych klauzulami generalnymi, uzależnionej od panujących w państwie stosunków polityczno-gospodarczych.

Przepis art. 55 k.z. przyznawal stronom generalna kompetencje do swobodnego ksztajtowania treści stosunków zobowiązaniowych w obrocie (autonomia kontraktowa sensu stricto). Z normy tej (w powiqzaniu jednak z innymi przepisami k.z.) można bylo wuloskować, iż zasada swobody umów obejmuje dalsze zasadnicze elementy - swobodę zawarcia lub niezawarcia unowy, możliwość nieskrępowanego wyboru kontrahenta oraz uwolnienie stron od formalizmu prawnego (swoboda umów sensu largo).

Szeroko ujmowanego zakresu treścjowego swobody umów nie kwestionowano $w$ doktrynie. Spory wywołak natomiast prteduniotowy zasięg obowiązywania zasady. Pojawił się bowien pogląd, iż wyrażona w treści alt. 55 k.z. zasada autonomii woli obejmowała, obok umów, także czy'nności ksztaltowana mogła być jedynie treść unów, brakowato jednak jakichkolwiek podstaw do argumentum a contrario, że swoboda ta nie dolyczyła takze czynności prawnych jednostronnych ${ }^{5}$. Poza tym, jak podkreślano w literaturze, z ogólu przepisów k.z. nie wynikato jednoznacznie, iż czymości prawne jednostronne stanowity źródło zobowiązań tylko w przypadkach wskazanych w ustawie ${ }^{6}$. Argumenty zwolenników uznania swobody umów jako obowiązującej także w odniesieniu do czynności prawnych jednostronnych okazały się lak silne, że nawet w świetle dostatecznie - jak sie wydaje - jasnej redakcji art. $353^{\prime}$ k.c. (i przy uwzględnieniu caloksztaltu

${ }^{4}$ Pryjęty przez ustanodawe przedwojennego model kompetencji generalnej w zakresie ks\%laltowania treści stosunków zobowiazaniowych w obrocie nie był jednak jedynym

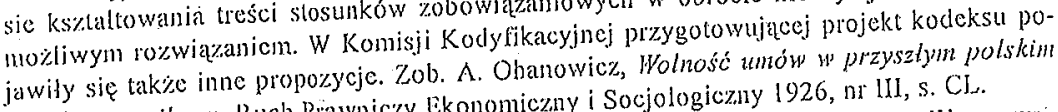
kodeksic cywilnym, Ruch Prawniczy Ekonomiczny i Socjologicziny 1926, mi III, s. Cl.

"Zob. S. Grzybowski w: System prawa cywilnego, t. I: Czesść ogólna, Warszawa-Wroclaw 1985, s. 467.

6 Tak $\Lambda$. Wolter, Czy art. 55 k.z. obowiqzuje?, Nowe Prawo 1960, mi 10, s. 1482. 

przepisów z zakresu prawa zobowiązań) pojawiają się tez wątpliwości co
do przedmiotowego zasięgu zasady swobody umów.

Za naruszenie wyznaczonych przez art. 55 k.z. granic autonomii kontraktowej ustawodawca przewidział sankcje w postaci bezwrględnej nieważności unowy (art. $56 \S 1 \mathrm{k} . z.)^{8}$. Do kryteriów wyznaczonych treścia normy art. 55 k.z. (ustawy, porządku publicznego i dobrych obyczajów) dodano jesscze niemożliwość obiektywną świadezenia, która także skutkowala nieważnościq unowy (impossibilizm nulla obligatio).

\section{Kwestia mocy wiązącej art. 55 kodelsu zobowiązań pod xxądani przepisów ogólnych prawa cywilnego}

Ze względu na dokonująca się $w$ Polsce $w$ okresie powojennym transformacje ustrojową i związanymi z nią przemianami spoleczno-gospodarczymi konieczna stała się nowelizacja przepisów prawa cywiłnego. W związku z tym wraz $z$ wejściem w życie 1 października $1950 \mathrm{r}$. przepisów ogólnych prawa cywilnego (dalej: p.o.p.c.) $)^{9}$ kwestia mocy obowiazującej normy art. 55 k.z. stala się przedmiotem szerszego sporu doktrynalnego ${ }^{10}$. Obszar zalstosowania przepisu był juz zreszta i tak znacznie ograniczony przcz przepisy szczególne regulujące umowy zawicrane w sektorze uspołecznionym (zwłaszcza w dziedzinie dostaw $i$ inwestycji z lat 1949-1950, 1956-1957).

Częsé doktryny stala na stanowisku, iz podstawą obowiązywania zasady swobody umów (choć w okrojonym znacznie zakresie) był formalnie nadal obowiązujący art. $55 \mathrm{k} . z$, którego nie derogowano ani przepisem szczególnym, ani ogólną klauzula derogacyjna przepisów wprowadzających p.o.p.c. (art. 1). Przewidziane w art. 55 ograniczenia miały być interpretowane w świetle zasad ustroju i celów państwa ludowego (zgodnie $z$ formula przepisu art. 4.1 \$ w związku $z$ art. 1 p.o.p.c.). Treść przepisu art. 41 1. p.o.p.c. nie dezaktualizowala w catości formuly art. 55 k.z; obie nomy mogly wspótistnieć w systenle prawa cywilnego ze względu na fakt, iż nie wykluczaty się wzajemnie. Przepis art. 41 \$ 1 p.o.p.c. miat jedynie szerszy zakres zastosowania - konstruował nieważność każdej czynności prawnej,

${ }^{7}$ Zob. np. M. Saljan, Zasada swobodý umów (uwagi wstepne na tle wyladani art. $353^{\prime}$ k.c.). Paístwo i prawo 1993, z. 4, s. 12.

S Specyfika lego przepisu polegala na tym, że odnosil się on wylącznie do unów, nie ustanaviając natomiast gencralnej sankcji nicwazności kazdej czynności prawnej.

${ }^{7}$ Ustawa $\% 1811.950 \mathrm{l}$. Przepisy ogólne prawa cywilnego, Dz.U. Nr 34, po\%. 311

$10 \mathrm{~W}$ doktynie polemika na ten temat toczyla się między A. Wolterem i J. Gwiazdomorskim na lamach Nowego l'rawa. Zob. A. Wolter, op.cit., s. 1335; J. Gwiazdomorski, Czy art. 55 kz obowiqzuje, Nowe Prawo 1960, ar 11, s. 1478; idem, Glosa do orzeczenia SN $z$ dnia 13 Vl $1958 \mathrm{r}$., Nowe Prawo 1960, $110 \mathrm{5}$, s. 708. 
natomiast norma art. $55 \mathrm{k}$.z. znajdowala zastosowanie jedynie do umów i obowiązywała w związku $z$ art. I p.o.p.c. w zakresie interpretowania ograniczeńn ${ }^{l !}$.

Przeciwnicy przedstawionej koncepcji z kolei przyjmowali, iż. przepis art. 55 k.z. zostal uchylony ogólną klauzula derogacyjną art. I przepisów wprowadzających p.o.p.c. Normatywna podstawą obowiązywania zasady wolności umów stała się zatem norma art. $41 \S 1$ p.o.p.c. ${ }^{12}$ Generalna kompetencja stron do kształtowania treści stosunków zobowiązaniowych w obrocie wynikata zeń jedynie pośrednio, a granice przyznanej stronom swobody kontraktowej zakreślaly przepisy ustawy oraz zasady współłycia spotecznego w panstwie ludowym. W takim ujęciu art. 55 k.z. zostat wchtonięty przez treść art. $41 \S 1$ p.o.p.c. ${ }^{13}$

Na jakiejkolwiek normalywnej podstawie by się nie oprzeć, faktem jest, iź swoboda umów nadal pozostawała zasadą fundamentalną - nie podważono bowiem samej kwestii jej obowiązywania na gruncie polskiego prawa zobowiazań. Ograniczeniom uległ jednak (w wyniku transformacji ustrojowej i związanych $z$ nią następstw natury ekonomicznej i spotecznej) zakres zastosowania zasady. Gospodarka zarząclzana centralistycznie i nakazowo w ramach własności spolecznej nie mogla w praktyce przyjąc koncepcji wolności unów w takim zakresie, jaki przewidywata norma art. $55 \mathrm{k} . z$.

Artykul 55 k.z. zostal formalnie uchylony dopiero I stycznia 1965 r., po wejściu w życie kodeksu cywilnego (art. I przepisów wprowadzających k.c.). Ustawodawca nie powrócił zatem do rozwiązań przedwojennych i nie umieścil w k.c. normy wyrażającej bezpośrednio zasadę wolności umów. Ulegla ona bowiem w powojennej Polsce tak daleko idącym ograniczeniom, ze - jak stwierdzono $w$ doktrynie $i$ judykaturze - nie godziło się jej proklamować expressis verbis. Po uchyleniu art. $55 \mathrm{k} . z$. w sposób bezpośredni zasadę swobody kontraktowej wyrazat jedynie art. 2 kodeksu morskiego ".

\section{Zasada swobody umów y ustawodawstwie polslim w latach 1965-1990}

W sferze obrotu uspolecznionego, charakterystycznego dla przyjętego w powojennej Polsce modelu zarzadzanej centralistycznie gospodarki nakazowo-rozdzielczej, opartej na systemie planowania i społecznej wlasności środków produkcji, swoboda umów uległa daleko idącym ograniczeniom ${ }^{15}$.

1 Tak A. Wolter, op.cit., s. 133.5.

12 Tak J. Gwiazdomorski, Glosa..., s. 708.

13 Tak idem, Czy arl. $55 \mathrm{k.z}$..., s. 1479.

14 Ustawn z 1 XII $1961 \mathrm{f}$ - Kodeks morski, lekst jedn. Dz.U. z $1998 \mathrm{r}$. Nr 10, poz. 36.

15 Zob. np. S. Buczkowski, op.cit., s. 435. Autor rozważa tam kwestię, czy w lzw. socja- 
Nie doszło jednak do całkowitego jej wyeliminowania ze sfery stosunków zobowiązaniowych, gdyż - jak konsekwentnie podkreślano w doktrynie $i$ orzecznictwie - autonomia kontraktowa była tak silnie związana $z$ gospodarką towarowo-pieniężną i jednocześnie tak mocno osadzona w porządku prawnym, że pomimo licznych ograniczeń pozostała fundamentalną zasada polskiego prawa zobowiazań. O obowiązywaniu zasady autonomii kontraktowej na obszarze gospodarki uspołecznionej decydowały więc jej ograniczenia ${ }^{16}$.

Obowiązywania zasady swobody umów nie podawano natomiast (pomimo braku normy prawnej wyrażającej ją w sposób bezpośredni) w wątpliwość w obrocie powszechnym (z udziałem wyłącznie jednostek niepaństwowych, a więc opartym na tzw. własności indywidualnej). W tej sferze obrotu autonomia kontraktowa przejawiala się nadal na charakterystyczhych dla niej ptaszczyznach (a więc swobody umów sensu stricto oraz sensu largo), przy uwzględnieniu jedynie ograniczeń ogólnych wyznaczonych treścią art. $58 \$ 1$ i 2 k.c. w związku $z$ art. 4 k.c. (doniostości ustroju spofeczno-ekonomicznego, gospodarczej funkcji państwa oraz względów moralności socjalistycznej ${ }^{17}$ ). W obliczu przewagi stosunków zobowiązaniowych opartych na własności spolecznej obrót powszechny miał jednak znaczenie marginalne i nie odgrywał większej roli w stosunkach gospodarczych (drobne rzemiosto, dzialalność usługowa).

Uznanie zasady autonomii kontraktowej, nawet w obliczu daleko idących ograniczen, za wiążącą w systemie prawnym wymagalo wskazania normatywnych podstaw jej obowiązywania. W związku z tym w doktrynie powoływano powszechnie normę art. 58 k.c., która w sposób negatywny wyrażala ogólną kompetencję do określania treści czynności prawnych (w tym takze umów). Na podstawie wnioskowania a contrario (z nieważności wszelkich czynności prawnych sprzecznych $z$ ustawそ zasadami współżycia spolecznego albo mających na celu obejście ustawy) nalezalo wnosić, że wszelkie czynności prawne (w tym umowy) o innej treści mogrty być ważnie dokonywane ${ }^{18}$. W tym sensie art. 58 k.c. stanowit generalne upoważmienie stron do kształtowanịa treści zawieranych umów zgodnie ze swoją wola jednocześnie wyznaczając ramy dopuszczalności swobody kontraktowej. Argumentum a contrario stanowiło jednak - jak wskazywa-

listycznym systemie gospodarki planowej zasada autonomii kontraktowej w ogóle mozc mieć rację bytu.

${ }^{16} \mathrm{Cz}$. Kulawska, Wokót zasady wolności umów (arl. $353^{\prime}$ k.c. i wyjktadnia zwyczaju), Acta Universilat is Wratislayiensis, Prawo CCXXXVIII, Wroclaw 1994, s. 174.

17 Więcej na temat tego rodzaju ograniczeń: A. Ohanowicz, J. Górski Prawo zobowiqzań w zarysie, Warszawa 1970, s. 80 i n.

18 J. Nowacki Wolność umów a uzasadnienie analogii, Państwo i Prawo 1966, z. I, s. 742 . 
no w doktrynie - zbyt słabe oparcie dla zasady swobody kontraktowej. Brakowało bowiem dostatecznych podstaw do określenia, czy ujęte w treści art. 58 k.c. ograniczenia zostały wymienione wyczerpująco (co jest niezbędua przesłanką dokonania wykładni a contrario).

Pewniejsze oparcie dla obowiazywania zasady swobody unów stanowil art. 56 k.c., który w sposób jednoznaczny i pozytywny statuowat generalna kompetencję w zakresie czynności prawnych (umów), proklamując jednocześnie regulę ksztaltowania treści umowy (jako rodzaju czyıności prawnej) przez zawierające ja podmioty (wykładnia jezzykowa). Działanie wzorca kompetencji generalnej normy art. 56 k.c. nie zostalo bowiem ograniczone ani wylączone przez przepisy ze skutkiem dla umów zobowiązaniowych. W szczególności zastosowanie tego wzorca oznaczało, że ustanowione w księdze III k.c. lub innych przepisach typy umów zobowiazaniowych (nazwanych) nie wyłączały kompetencji stron do zawarcia, zgodnie ze swoją wola, umowy o odmiennej treści (mieszanej albo nienazwanej) ${ }^{19}$. Wzorzec kompetencji generalnej oparty na normie art. 56 k.c. i potwierdzony treścią art. 58 k.c. nie tylko nie pozostawał w sprzeczności z przepisami k.c. dotyczącymi treści zobowiązań umownych, ale doznawal tam szczególnego wsparcia w przepisach szczególnych ${ }^{20}$.

Obowiazywanie wzorca kompetencji generalnej w zakresic ksztaltowania stosunków zobowiązaniowych w obrocie potwierdzata judykatura arbitrażowa. W orzeczeniu z dnia 19 lipca 1971 r. GKA stwierdzila, iż wobec braku odnoszacych sję do danego typu umownego stosunku prawnego dyrektywnych dyspozycji organów kierujących gospodarką uspołeczniona strony w granicach ogólnych zasad prawa dysponowaly swobodą w ksztaltowaniu treści przedmiotowej umowy ${ }^{21}$. Wzorzec kompetencji generalnej nie ustalit się jednak dostatecznie $w$ świadomości ówczesnych podmiotów gospodarczych (zwłaszcza zaś j.g.u.), które skłonne były raczej czekać na odgóne przekazanie schematów i zgodnie $z$ nimi ksztaltować stosunki umowne ${ }^{22}$.

Przepisy art. 56 i 58 k.c., będące normatywnym potwierdzeniem zasady swobody umów ustanawiały regułę ksztaltowania treści umowy (jako jednej z. postaci czynności prawnych, nola bene o najdonioślejszym znaczeniu)

${ }^{12}$ Zob. Z. Radwański, op.cit., s. 110.

${ }^{30}$ Nic spotkal się natomiast $z$ aprobatą ani w literaturze, ani w piśmiennictwie pogląd, iz nomatywną podstawę obowiązywania zasady swobody umów stanowily takze przepisy art. $2 \mathrm{i}$ art. 189 k.p.c. (ewentualnie takźc art. 1 k.c.), klórc nakazywaly rozstrzyganic wszelkich spraw cywilnych niezalcżnic od tego, czy określony przypadek zostal unormowany konkretnymi przepisami. Nakaz rozstrzygania spraw cywilnych zachowywal bowicm aktualność przy jakimkolwiek sposobie unormowania zakresu zasady swobody unów. Tak. J. Nowacki, op.cit., s. 742.

21 Przeglnd Uslawodawslwa Gospodarczego 1972, nr 3, poz. 920.

${ }^{22}$ Cz. Zulawska, op.cit., s. 174. 
przez podniot, który jej dokonywal (swoboda umów sensu siriclo). Wolność kontraktowa przejawiać się jednak mogła także na pozostałych plaszczyznach, a więc w zakresie decyzji odnośnie do zawarcia bądź niezawarcia umowy, wyboru kontrahenta oraz formy (swoboda umów sensu largo). Zakres obowiązywania zasady swobody umów był jednak na każdej z plaszcżyzn tak dalece ograniczony, że pozostawione faktycznie stronom ramy swobody tatwiej było wyznaczyć poprzez wskązanie ogranic\%eń. Przyjęły one bowiem postać szczególną, uwartinkowaną charakterystyc\%nymi dla owczesnego ustroju stosunkami spoteczno-gospodarczymi.

W stosunkowo najmniejszym zakresie autonomia kontraktowa stron w obrocie uspolecznionym przejawiała sie na plaszczyznie ksztaltowania treści zobowiązania.

Ustalenie warunków umowy w sposób odmienny (a odpowiadający woli stron) nie było możliwe w zakresie, w jakim regulacje umów mialy charakter imperatywny, tzn. objęte były wskazanym normatywnie wzorem w postaci ins cogens ${ }^{23}$. Poza tym stronom nie przystugiwata kompetencja do swobodnego ksztaltowania treści stosunku zobowiazaniowego na tych obszarach stosunków spotecznych, które ustawodawca wylącryl mo\%liwość negocjacji (przepisy, w tym administracyjno-prawne, dotyczące cen sztywnych, obowiazujących norm technicznych, ustalające odgórnie terminy świadczen umownych, przepisy o rejonizacji etc.).

Autonomie stron $w$ omawianym zakresie ograniczała naczelna zasada planowości (stanowiąca podstawę obrotu uspotecznionego). Ustalane odgómie wskaźniki planowe określaty jedynie końcowy wynik dziatalności gospodarczcj, nie wyznaczając jednocześnie norm prawnych i kompetencji j.g.u. do realizacji nalozonych na nie zadań planowych. Sam jednak fakt, i kontrahenci osiagnąć mieli wskazany planem cel, powodowat, ze treść zawieranej umowy podporządkowano wykonaniu zadań planowych. Ro\%klad wzajemnych praw i obowiązków nie stanowit więc przejawu swobodnej woli stron, lecz byt ksztattowany przez cel umowy ${ }^{24}$.

Ponadto, w przypadku jakichkolwiek wątpliwości bądź sporów stron odnośnie do treści umowy, kompetencje do jej ustalenia miala (jakkolwick na wniosek stron) Państwowa Komisja Arbitrażowa (art. 4 ustawy o PAG) ${ }^{25}$. Wola stron pozostawiona została zatem na drugim planie.

23 "Imperatywizacja” przcpisów z zakresu zobowiq̨ań stanowila jeden z præejawów charakterystycznego dla ówczesnego ustroju instrumentalnego podejscia do prawa, które traktowane bylo jako narzedzie bezpośredniego kierowania zachowaniani adresatów. Więcej na len temat Cz. Zulawska, op.cit., s. 174 i 17.

${ }^{24} \mathrm{~S}$. Wlodyka, Doskonalenie organizacji i dzialalnośsi arbitrazu państwowego w warunkach zmian in systemie zarzqdzania, Pryegląd Ustawodawslwa Gospodarc\%go 1972, in: 8-9, s. 268-269.

${ }^{25}$ Ustawa z 23 X 1975 «. o Państwowym Arbitrazu Gospodarc\%ym, D\%.U. Nr 34, po\%. 183. 
Z kolei swoboda zawierania umów (bądź rezygnacji z ich zawarcia) ograniczona była poprzez odpowiednie przepisy prawa ustanawiające reżim, t.zw. umów obowiązkowych. Obowiazek zawarcia umowy spoczywał w obrocie uspołecznionym na j.g.u. (art. 307-404 k.c.), a w obrocie mieszanym - na tych jednostkach pańștwowych, do których statutowych zadań należato świadczenie różnorodnych usług bytowych na rzecz ludności (np. transportowych, przewozowych, ubezpieczeniowych). Źródłem obowiązku kontraktowania mogły być zarówno umowa przedwstępna (art. 389 i 390 k.c.) i inne przepisy ustawy nakładające obowiazzek zawarcia umowy, jak równiez. decyzja administracyjna (art. 397 k.c.) oraz statutowe zadania j.g.u. ${ }^{26}$ Istnienie obowiązku kontraktowego w obrocie między j.g.u., a w praktyce tez - jak juz wspomniano - w obrocie mieszanym, determinowato jednocześinie wybór kontrahenta.

\section{Swoboda umów w świetle normy art. $353^{l}$ kodelssu cywilnego}

Zanim zasada swobody umów znalazla podstawy normatywne w postaci wyrażającego ją expressis verbis przepisu art. $353^{1}$ k.c., jurydycznym potwierdzeniem jej istnienia $w$ świetle przemian politycznych i spoleczno-gospodarczych stała się wyrażana w Konstytucji zasada wolności gospodarczej ${ }^{27}$. Stanowisko to potwierdził Sąd Najwyższy w uchwale $z 10$ stycznia $1990 r^{28}$ przyjęto w niej, że (w przypadku braku jakichkolwiek ustawowych ograniczeń lub wyłączeń omawianej zasady) generalne domniemanie na rzecz wolności oraz związana z nim dyrektywę interpretacyjna in farorem libertatis odnosi się także do swobody kontraktowej (stanowiącej część konstycucyjnej zasady wolności gospodarczej). Decydowała o tym rola unowy w obrocie gospodarczym, w którym stanowita ona podstawę wszelkich działań stron ${ }^{20}$.

Przepis art. $353^{1}$ k.c. został wprowadzony do k.c. nowela z 28 lipca $1990 \mathrm{r}^{30}$ Ustawodawca powrócit tu do rozwiązań przyjętych w k.z. ${ }^{31}$ Kon-

Treśc umowy ustalano w świelle nalozonego na określona jednostkę zadania doskonalenia systemu umów w stosunkach mięclzy j.g.l., zgodnie z kicrunkami gospodarczymi kraju i przy uwzględnicniu przede wszystkim interesów państwa.

${ }_{20}$ Por. Z. Kwaśnicwski w: Prawo obrotu gospodarczego, Warszawa 1987, s. 100-101.

${ }^{27}$ Ustawa \% 28 XII 1989 r. o \%mianie Konslylucji, D\%.U. N. 75, po\%. 444.

28 OSN 1990, poz. 74.

29 Z. Radwański, Prawo cywilne. Cześci ogólna, Warszawa 1999, s. 180.

. Ustawa $\% 28$ VII 1990 1. o zminnic ustawy - Kodcks cywilny, Dz.U. z 1990 i. Ni 5.5, po\%. 321 .

31 Wspólcześnic uważa się w dokurynie, ze wyraźnie zasady swobody umóv expressis 
cepcja wyrażona w art. $353^{\prime}$ k.c. zbliża się bowien w znacznym stopniu do syntetycznej formuly wolności umów, jakq̨ stanowil art. 55 k.z., także gdy chodzi o kryteria wyznaczające zakres przyznanej stronom swobody ksztaltowania treści zobowiązania. Powrót (w sensie zarówno technicznym, jak i jurydyczny'm) do koncepcji przedwojennych uznaje się w doktrynie za wtaściwe rozwiazanie. Nawiazuje ono bowiem do tradycji wspólnej wszystkim niemal kodyfikacjom zachodnioeuropejskim, co niewątpliwie ma duże znaczenie w przededniu wejścia Polski do Unii Europejskiej. Przepis art. $353^{1}$ k.c. ma bowiem walor modelu, ná którym opiera się wspótczesny system umów ${ }^{32}$. Jego obecność w k.c. usuwa wszelkic wątpliwości co do rangi i znaczenia przypisywanego autonomii woli stron w'ksztaltowaniu wszelkich (w ramach wskazanych ustawa) stosunków zobowiązaniowych (bez względu na sektor whasności i rodzaj obrotu). Jednocześnie pozwala także przywrócić klasyczną dyrektywę interpretacyjną (obecna pod rządami k.z. i niejako "odwrócona" w latach 1965-1990), zgodnie z którą normy prawa zobowiązań są co do zasady dyspozytywne. Wyjatek stanowia jedynie te normy prawne, z których brzmienia wyraźnie wynika charakter imperatywny oraz te, które wyrażają zasadę moralną bądź ich treść jest odzwierciedleniem istotnego celu społeczno-gospodarczego ${ }^{3.3}$.

\section{Zasięg przedmiotowy i plaszczyzny zastosowania zasady swobody unów}

Umiejscowienie art. $353^{\prime}$ k.c., a w przede wszystkim jego treść („strony zawierające unowę...") pozwalają przyjąc teze, iż zasada swobody w prawie polskim odnosi się wyłącznie do umów ${ }^{34}$. Wyklucza to jej zastosowanie w stosunku do innych źródeł powstania zobowiąania, w tym także do czynności prawnych jednostronnycli ${ }^{35}$. Stanowisko to w zasadzie nie wywotuje już sporów i wątpliwości - w doktrynie panuje obecnie zgodny pogląd co do tego, iż czynności prawne jednostronne dokonywane są w ra-

verbis $w$ k.c. stanowi jedynic potwierdzenie stanu istnicjącego od momentu uchylenia przepisu art. 55 k.z. Por. Cz. Zulawska op.cit., s. 174; M. Safjan, op.cit, s. 12 i $\mathrm{n}$.

32 Tak. Z. Radwański, Teoria..., s, 33.

3s Zob. Cz. Zuławska op.cit., s. 175; T. Wiśnicwski w: Kodeks cysvilny, Komentarz. Ksiega llI - Zobowiqzania. Część ogólna, pod red. T. Piẹtrzykowskiego, Warszawa 1996, s. 13.

3.1 W doktrynie przyjmuje się ponadı, iż rezimowj przepisu art. $353^{1}$ k.c. podlegać będa także unowy uregulowane w imnch niż k.c. aktach prawnych, np. obligacyjne umowy prawa autorskiego, kontrakty z zakresu prawa wynalazczego i wiasności intclektualnej, przy uwzględnieniu oczywiście przesłanek i wymogów stawianych przez odpowiednic przepisy szczególne (prawo autorskie i wynalazcze).

3s Tak. M. Safjan, op.cil., s. 12 in. 
mach szerszej niż swoboda umów zasady autơnomii woli. Te ostatnią określa się $w$ doktrynie jako uprawnienie do samodzielnego wplywania podmiotów na ich sytuację prawną (np. swoboda testowania) ${ }^{36}$.

Przepisu art. $353^{1}$ K.c. nie stosuje się także do stosunków z zakresu prawa rzeczowego, spadkowego oraz rodzinnego. Wynika to $z$ faktu, iz w stosunkach tego rodzaju mamy do czynienia z mumerus clausus czynności prawnych, jakich strony mogą dokonać (prawo rzeczowe), bądź też. stąd, że regulacja danych stosunków ma charakter w większości imperatywny i samodzielność podmiotów nie wchodzi w związku z tym w rachubę (prawo rodzinne, spadkowe). Nie oznacza to jednak, że w ramach omawianych typów stosunków niedopuszczalna jest jakakolwiek swoboda stron w ksztattowaniu treści zawieranyclı umów, kiedy prawo taką możliwość przewiduje (np. zawarcie majątkowej umowy małżeńskiej, w której strony decydują się na rozdzielność majątkowa ${ }^{37}$.

Artykuł $353^{\prime}$ k.c. wyraża zasade swobody umów rozumiana sensu stricto. Kompetencja stron w zakresie kształtowania treści stosunku zobowiązaniowego zgodnie z ich wola jest stosunkowo szeroka i przejawia się na kilku płaszczyznach.

Po pierwsze, istnieje możliwość przyjęcia przez strony jakiejkolwiek modyfikacji określonego typu umowy nazwanej (uregulowanej w k.c. bądź przepisach szczególnych) i ustalenia treści konkretnej umowy w taki sposób, że jej postanowienia odbiegać będa od wzorca normatywnego, nie naruszająe jednak essentialia negolii. Przepisy danego typu umowy nazwanej o charakterze iuris dispositivi znajda zastosowanie dopiero w braku odmiemnych postanowień stron odnośnie do danej kwestii. Swobodę kontrahentów ograniczać będą zatem jedynie dotyczące danej umowy nazwanej przepisy imperatywne (iuris cogentis) ${ }^{38}$.

Po drugic, strony mogą zawrzeć umowe mieszaną, tzn. wprowadzić do kontraktu nazwanego tak znaczace modyfikacje (zwłaszcza w rakresie składników przedmiolowo istonych), że umowa nie będzie się mieścić w ramach wyznaczonego ustawą typu. Odmienności te moga polegać na uzupełnieniu unormowania ustawowego różnego rodzaju postanowieniami dodatkowymi (klauzulami, zastrzezeniami), umieszczeniu w umowie uzgodnień regulujących pewne zagadnienia odmiennie niz ustawa bądź na wyłączeniu zasto-

36 Zub. J. Skapski, Autonomia woli w prawie prywatnym międzynarodowym w zakresie zobowiqzań z umów, Kraków 1964, s. 21.

37 Problematyka zakresu samodzielności podmiotów w zawicraniu umów uależacych do prawa rodzinnego, spadkowego i rzeczowego wykracza poza amy opracowania i nie będzie precedmiotem dalszej analizy.

${ }^{38}$ Pojawiana sie one jednak wyjątowo, gdy pewne zasady uznane zostaną procz przepisy prawa przedmiotowego za bezwzględnie obowiązujące $w$ danej dziedzinie slosunkow wymiany dóbr i ushọg. Zob. T. Wiśnicwski, op.cit., s. 13. 
sowania określonych przcpisów. Możliwe jest także połączenie kilku cech umow nazwanyeh ${ }^{39}$.

Swoboda ksztattowania treści umów obejmuje także możliwość zawarcia umowy nienazwanej, w której strony ustala wzajemne prawa i obowiazki (ewentuainie umieszcza dodatkowe zastrzeżenia umowne, jak np. zadatek, odstepne, kara umowna etc.) całkowicie według swojego uznania, aczkolwiek w granicach zakreślonych treścią normy art. $353^{\prime}$ k.c. Umowa taka nosić będzie w sobie clement całkowitej nowości względem którejkolwiek z umów nazwanych.

Ustanowiony i uksztaltowany wolą stron stosunek zobowiazaniowy (zalrówno w postaci umowy nazwanej, jak i mieszanej czy nienazwanej) może być z kolei późniejszą umową zmieniony. Obowiązuja przy tym te same założenia, które leżą u podstaw ważnie zawartej umowy ${ }^{40}$.

Problematyka prawna wolności umów wykracza jednak znacznie pozal normatywne ramy art. $353^{\prime} \mathrm{k}: \mathrm{c}$. i nie obejmuje jedynie swobody ksztaltowania treści stosunków zobowiązaniowych. Odwołanie się do innych przepisów k.c. (nie tylko o zobowiązaniach umownych) w ramach analizy zasady swobody umów pozwala stwierdzić, że zakres autonomii kontraktowej w prawie polskim obejmuje dalsze, charakterystyczne dla tej zasady elementy.

Po pierwsze, swoboda umów oznacza samodzichność decyz.ji kontrahentów w kwestii zawarcia lub niezawarcia umowy. Podmiot zatem sam rozstrzyga czy określona potrzeba zostanie zaspokojona przez świadczenie z. umowy czy w inny sposób. Raz zawarta umowa moze być następnie wola stron roxwiązana. Kontrahentów w zasadzie wiąze generalna formula pac/a servanda sunt, jednakże w przypadkach określonych w ustawic (cwentualnie $w$ unowie) każda ze stron moze zrealizować decyzję o zakończeniu stosunku zobowiązaniowego przez odstapienie od umowy".

Po drugie, wolność wyraża się w swobodzie wyboru kontrahenta (obecnie równieź zagranicznego), z którym umowa ma być zawarta.

Po trzecie, swoboda umów oznacza daleko posunięte uwolnienie od formalizmu prawnego. W stosunkach,zobowiazaniowych przewaza bowien reguła, że prawnie skuteczne jest samo poroztumienie stron, nie wymagające formy szczególnej. Oznacza to, że strony moga dowolnie wybrać formę umowy. Swobodę w tyn zakresie ograniczają jedynie imperatywne przepisy o formie pisemnej ${ }^{42}$, względnie szczególnej (akt notarialny) ${ }^{43}$ dla określo-

${ }^{39}$ Scisle określenic pojęcia unów mieszanyeh jest w doktrynie uznawanc za kontrowersyjne. Zob. W. Czachórski, Zobowiazania. Zarys wykladu, Warszawa 1994, s. 107-m108.

${ }^{40}$ Idem, Prawo zobowiqzań w zarysie, Wars\%awa 1970, s. 190.

"11 Cz. Zuławska, Zasady prava gospodarczego prywalnego, Warszawa 1995, s. 4.8-49.

Por: art. 75 k.c., art. $720 \$ 2$ k.c.

13 Por, art. 80 k.c., art. 158 k.c., art. ' 179 k.c., art. $236 \$ 3$ k.c., art. 1037 \$ 2 k.c., art. 1048 k.c., art. 1050 k.c., art. $1052 \$ 3$ k.c. 
nych rodzajów umów. Przepisów tych jest jednak niewiele, gdyż większość umów nie wymaga formy szczególnej. Kwestia, czy przepisy o formie rzeczywiście stanowia ograniczenie autonomii kontraktowej stron, jest jednak sporna $w$ doktrynie ${ }^{44}$.

Po czwarte, w wypadku tzw. kontraktów międzynarodowych, gdy miejsca zamieszkania (siedziby) kontrahentów znajdują się na terenie różnych państw, swoboda kontraktowa obejmje także wybór prawa dla zobowiązań wynikajacych $z$ umowy (tzw. prawo kontraktu). Zgodnie bowiem z art. 25 $\$ 1$ ustawy o prawie prywatnym mięlzynarodowym ${ }^{45}$ strony moga poddać stosunki wynikające $z$ umowy wybranemu przez siebie prawu, jeżeli pozostaje ono w zwiazku $z$ umowa i wedlug tego prawa oceniana będzie prawidlowość zawarcia kontraktu, jego formal i treść.

Po piąte, za przejaw swobody kontraktowej uznaje sie w doktrynie i judykaturze również możliwość dokonania przez strony (w granicach wynikających z odpowiednich przepisów) wyboru sądu, który rozpozna ewentualne spory pojawiające sie $w$ zwiazku $z$ zawarciem lub wykonaniem umowy. $Z$ zasadą wolności umów harmonizuje w tym wrględzie dopuszczalność zapisu na sąd polubowny (niedopuszczalna w gospodarce planowej). Nie ulega bowiem wątpliwości fakt, iż skutki rozstrzygnięcia wynikającego $z$ umowy sporów na drodze sądowej muszą mieć oparcie w zgodzie stron $^{46}$. Należatoby się jednak zastanowić, czy możliwość wyboru rozstrzygnięcia przez sąd, zarówno państwowy, jak i polubowny nie stanowi wyrazu szerszej niż swoboda kontraktowa koncepcji autonomii woli stron.

W doktrynie pojawito się pytanie, czy autonomia kontraktowa obejmuje również możliwość uabstrakcyjnicnia umowy, która normatywnie ukształtowana została jako czynność prawna kauzalna, jeżeli taki zamiar objęty byt wolą kontrahentów i wyraźnie wy'nikạt $z$ treści zobowiązania ${ }^{47}$. Za szerokim rozumieniem zasady swobody umów, dopuszczającym możliwość objęcia wolą stron także "woli abstrakcji”, opowiedział się Sąd Najwyższy

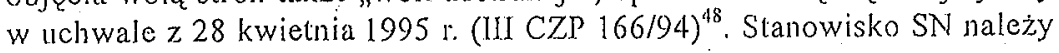

$\$ 1$ zob. Z. Radwański, Teoria..., s. 102 i n. Zdaniem autora wymóg zachowania formy nic ogranicza swobody umów w rozumieniu prawnym, gdy\% nic dolyka bezpośrednio przyznanej stronom kompetencji do ksztaltowania treści zobowiqzania i tym samym nie ogianicza wolncj woli czlowicka wyrażonej w zasadzie konsensualizmu. Odmicmnie A. Ohanowic\%, op.cit,, s. X. Autor wyraza pogląd, iz "wszclkic przyrzeczenie, nawet nieformalne, rodzi zaskáżalne zobowiązanie".

${ }^{15}$ Ustawa z. 12 XI 1965 r., D\%.U. Nr 46, poz. 290.

\$o Tak C.. Zulawska, Zasady..., s. 50.

17 Tak M. Safjan, Úmowy zwiqzane z obrolem gospodarczym jako najważnicjsza kalegoria czynnosici handlowych, Preglad Prawa Fandlowego 1998, n. 2, z. 1., s. 6.

${ }^{18}$ OSNCP 1995, z. 10, poz. 135. Omawiany problem pojawil się na tic oceny charakteru prawnego gwarancji bankowej opatronej klauzulami „nicodwolalnie i bezwarunkowo" oraz 
uznnać za sluszne. Dopuszczenie możliwości wykluczenia kauzalności umowy przez strony na rzecz stosunku abstrakcyjnego uzasadniaja potrzeby iowoczesnego obrotu, zwłaszcza zaś dążenie do maksymalizacji zasady jego bezpieczeństwa ${ }^{49}$.

ra

\section{Granice swobody umów $x$ art. $353^{1}$ k.c.}

Przepis art. $353^{1}$ k.c., wyraźając expressis verbis zasade swobody umów, stanowi normatywne potwierdxenie jej istnienia na gruncie polskiego prawa zobowiązań. Jego doniosłość jurydyczna wyraża się również w tym, iž zakreśla on jednocześnie dopuszczalue granice przyslugującej stronom swobody kontraktowej. Treść omawianego przepisu potwierdza zatem przyjhiowany $w$ doktrynie $i$ orzecznictwie pogląd, iż swoboda stron w ksztaltoyaniu stosunków obligacyjnych nie ma charakteru absolutnego i co do zasady podlega różnego rodzaju ograniczeniom. Ograniczenia te są koniecztie, gdyż stanowią właściwe ramy organizacyjne dla swobody kontraktowej, a lym samym - zapewniaja jak najpełniejsza jej realizację. System prawny niie może bowiem udzielić stronom nieograniczonej kompetencji do kreöwania stosunków umownych o doniosłości prawnej, a w konsekwencji ५ózostawić tę sprawę poza kontrola państwa. Zasada swobody umów może być bowiem realizowania jedynie przy zachowaniu wymogów bezpieczeństwa obrotu.

Ogran iczenia zasady swobody umów stanowią w świetle art. $353^{\prime}$ k.c. kiyteria odnoszace się do właściwości (natury) stosunku prawnego, ustawy oraz zasad wspólżycia społecznego. $Z$ bezwzględnie obowiązującego charakteru art. $353^{1}$ k.c. i związanego z tym nakazu ścisłej jego interpretacji jako wyjatku na tle dyspozytywnej co do zasady regulacji prawa zobowiazań (exceptiones non sunt extendendae) wynika, iż nie jest moźliwe jakiekolwiek dalsze, dowolne poszerzanie katalogu ograniczeń o elementy nie vyrażone bezpośrednio w jego treści ${ }^{50}$. Wymienione kryteria sa zatem jedynymi możliwymi wyznacznikami zakresu autonomii kontraktowej.

Porównując aktualne kodeksowe ujęcie formuly zasady swobody umów zi treścią art. 55 k.z., można dojść do wniosku, że katalog kryteriów ograni\#czajacych autonomię stron w zakresie ksztaltowania stosunków obligacyjChych nie uległ w zasadzie wieksszym zmianom. Nie zmienione pozostato tis

7t, nia pierwsze ządanie", klórcj abstrakcyjny charakter (jako cecha zasadnicza) nie zostat pôtwierdzony przepisami ustawy.

4. 49 Trzeba jednak zauważyć, że oceny tego orzeczenia SN w doktrynic są rozbieżne. Por. A. Szpunar, Zabezpieczenia osobisle wierzylelnosici, Sopot 1997, s. 160.

so Por. Cz. Zulawska, Wokól...; s. 175-176; Z. Radwaniski, Zobowiqzania. Część ogólna, Warszawa 1997, s. 43. 
ograniczenie ze względu na ustawę. Rezygnacja z ograniczenia w postaci klauzuli generalnej porzadku publicznego, podyktowana była - jak sie wskazuje w literaturze - tym, iż obecnie dokonanie czynności prawnej sprzecznej z tym porządkiem stanowi najczęściej jednocześnie naruszenie przepisów ustawy, ewentualnie - zasad wspólżycia spolecznego ${ }^{31}$. W odniesieniu do kryterium dobrych obyczajów (w szerokin ujęciu) należy zauważyć, że pokrywa się ono w dużym stopniu z obecną na gruncie wspótczesnej regulacji wspomnianq klauzulą generalną zasad współżycia społecznego, która - zapożyczona od „socjalistycznego" ustawodawcy - nabrala obecnie nowej treści. Novum legislacyjne stanowi natomiast kryterium właściwości (natury) stosunku prawnego. Jest to klauzula generalna niespotykana dótychczas w płaszczyźnie normatywnej polskiego prawa cywilnego.

Nawiązaniem do regulacji przyjętych pod rządami art. 55 k.z. jest również odniesienie wymienionych $w$ art. $353^{\prime}$ k.c. ograniczeń zarówno do treści, jak i celu powstającego w wyniku zawarcia umowy stosunku obligacyjnego.

Cel zobowiązania, w świetle art. $353^{1}$ k.c., stanowi odrębna od treści stosunku prawnego kategorię prawna, na podstawie której dokonuje się oceny zgodności z kryteriami wyznaczajacymi zakres swobody kontraktowej ${ }^{\text {j2 }}$. Jest on zindywidualizowany dla każdego zobowiązania i oznacza korzyści gospodarcze, jakie strony (albo przynajmniej jedna z nich) zamierzają osiągnąc $w$ wykonaniu zobowiazania. Cel powinien pozostawać w bezpośrednim związku z treścią dokonywanej czynności (czynność nakierowana wprost na jego osiagnięcie) i być objęty świadomością obu stron ${ }^{53}$. Nie jest natomiast konieczne, by wynikat on z treści czynności prawnej ${ }^{54}$.

W odniesieniu zaś do treści stosunku zobowiazaniowego należy mieć na uwadze to, że jej zakres jest znacznie szerszy niż wynikałoby to z zawieranej przez strony umowy. Treść powstającego zobowiązania obejmuje bowiem nie tylko ustalone przez strony $w$ umowie ich wzajemne prawa i obowiązki dotyczące samego świadczenia oraz jego spelnienia (treść umowy) ${ }^{55}$, ale równiez (zgodnie z normą art. 56 k.c.) te, które wynikają z usta-

st Niektórzy autorzy uważạą, ze klauzulę porządku publiczncgo zastapiła w art. 353 k.c. klauzula natury (wlaściwości) stosunku prawnego. Zob. A. Stelmachowski, $W(s / e)$ do teorii prawa cywilnego, Warszawa 1998, s. 97.

52 Celu stosunku prawncgo w rozunieniu att. $353^{\prime}$ k.c. nic natezy utozsamiac \% przyczyna prawną zobowiązania (causa), z której istnieniem wiąze się podzial czynności prawnych na przyczynowe (kanzaine) i oderwane (abstrakcyjnc). Tak T. Wiśniewski; op.cit., s. 14.

${ }_{53}$ Tak T. Wiśniewski, op.cit., s. 14; A. Rajski, Prawo o kontrakfach w obrocie gospodarczym, Warszawa 1994, s, 43; Z. Radwański, Zobowiqzania..., s. 122.

54 Odmiennie A. Wolter, Prawo cymilne. Zarys części ogólnej, Warszawa 1986, s. 266.

is $\mathrm{l}$. Wiśniewski, op.cit., s. 14. 
wy, zasad współzycia spotecznego oraz ustalonych zwyczajów. Wymienione wskaźniki, współksztaltujące treść stosunku zobowiązaniowego, powinny być każdorazowo uwzględniane przy ocenie jego zgodności z klórymkolwiek ze wskazanych wart. $353^{\prime}$ k.c. ograniczeń zasady swobody umów.

Przekroczeniem zakreślonych przez art. $353^{\prime}$ k.c. granic wolności kontraktowej jest naruszenic choćby jednego z wymienionych kryteriów. Reguiacje we wspomnianych dziedzinach krzyzują się jednak, stąd zakaz ustalania celu i treści umowy w określony sposób może wynikać jednocześnie z ustawy, zasad wspólzycia społecznego i natury stosunku. Wykładnia art. $353^{1}$ k.c. wymaga więc od interprelatora ustalenia wzajemnych relacji miedzy tymi kryteriami ${ }^{36}$.

\section{Ograniczenia swobody unów ze względ u na ustawe}

Zgodnie z pogladami przyjętymi w literaturze, ustawa stanowi najlatwiej uchwytua granice wolności kontraktowej ${ }^{57}$.

W świetle art. $353^{1}$ k.c. kryterium ustawy spełniają - z jednej stronyte wszystkie regulacje o charakterze zakazów opatrzonych sankcją karna, zawarte w przepisach prawa: karnego, administracyjnego, konstytucyjnego, zktórych wynika zakaz kszaltowania stosunków cywilno-prawnych o określonej treści. Z drugiej strony becla to przepisy prawa cywilnego o charakteize bezwrględnie obowiązującym (itwis cogentis), m.in. zagrozone cywil. noprawną sankcją nieważności (np. umowa o złożenie fałszywych zeznań, o niepłacenie alimentów na rzecz najbliższego czlonka rodziny, pomimo istnienia pelnych mozhiwości realizacji tego obowiązku).

Bezspolne w doktrynie jest równiez to, iz pod pojęcien ustawy w świetle art. $353^{\prime}$ k.c. rozumieć należy także tzw. normy semiimperatywne ${ }^{58}, \mathrm{tj}$. takie, których bezwzględnie obowiązujący charakter działa w jednym tylko kierunku. Przyktadem sprzeczności z normą semiimperatywną będzie naruszenie postanowień przepisów ustalających ceny maksymalne przy splzeda$\dot{z} y$ (art. 538 k.c.) i minimalne przy kontraktacji (art. $613 \$ 3$ k.c.).

Odwolując się do ustawy jako kryteriun ograniczającego zasade swobody umów, należy mieć na uwadze szczególną dyrektywę interpretacyjna, która nakazuje jako inss cogenes traktować tylko te pizepisy, z których brzmienia wyraźnic wynika ich bezwzględnic obowiazujący charakter lub też te, których treść jest wyrazem zasady moralnej albo odzwierciedleniem

36 J. Guśc, O wlaściwości (naturze) stosunku prawnego, Pans(wo i Prawo 1997, \%. 4, s. 16.

${ }^{57}$ M. Safjan, Zasada..., s. 15.

${ }^{38}$ Z. Radwanski, Zobowiqzania..., s. 119 i n.; M. Salfan, Zascady..., s. 15; C\%. Zutawska, Zasady..., s. 49 i n. 
jakiegoś istotnego celu spoleczno-gospodarczego ${ }^{59}$. Ustawodawca wymaga zatem od stron daleko idącej ostrożności w ustalaniu, które przepisy należeć będą do bezwzględnie obowiązujących, gdyż zasadą jest względnie obowiazujący charakter norm regulujących stosunki zobowiązaniowe.

Ograniczenie swobody kontraktowej stron w kształtowaniu treści stosunku prawnego przez przepisy bezwzględnie obowiazujące (a w tym semiimperatywne) podyktowane jest przede wszystkim potrzebą wzmożonej ochrony występujących w obrocie podmiotów przed ujemnymi konsekwencjami tej swobody, przejawiajacymi sie przede wszystkim w postaci nadużyć ze strony silniejszego ekonomicznie kontrahenta. Motywem dla regulacji imperatywnych może być również jeden z podstawowych postulatów prawa cywilnego, mianowicie zachowanie bezpieczeństwa obrotu (np. art. 526 k.c., art. 661 k.c.).

Ram swobody kontraktowej nie stanowią natomiast, w świetle art. $353^{\prime}$ k.c., przepisy wrględnie obowiązujące (iuris disposilivi). Regulacja dyspozytywna tworzy wzorcowy i optymalny $z$ punktu widzenia prawa model, który stuzy jako punkt odniesienia przy interpretowaniu konkretnej umowy i ocenie jej odmiennych uzgodnień z punktu widzenia natury tej umowy i zasad współżycia. W razie sprzeczności umowy \% tego typu norma nie zunajdzie ona zastosowania, a treść stosunku zobowiązaniowego regulować bedzie umowa (jako norma indywidualnie ustanowiona wola stron). Przepisy dyspozytywne z natury swojej odgrywać więc będą rolę ochronną jedynie pośrednio ${ }^{60}$.

Nie każdy jednak przepis o charakterze bezwzględnie obowiązującym stanowi wyznacznik granic swobody kontraktowej. Pojęcic ustawy należy interpretować ściśle, jako obejmujące jedynie normy wyẋszego rzędu zawarte w samej ustawie bąd́́ wydane na podstawie wyráznego upoważnienia ustawowego ${ }^{61}$. Z zakresu unormowania wyeliminować należy natomiast uregulowania zawarte $w$ aktach niższego rzędu, a więc zarządzeniach, uchwatach, wytycznych etc.

Nalezy również zaznaczyć, ze na tle art. $353^{1}$ k.c. pojęcie sprzeczności stosunku prawnego z ustawą należy rozumieć jako sprzeczność z normą (imperatywná bạdź semiimperatywna) zrekonstruowaną w szczególności na podstawie przepisów prawnych ${ }^{62}$. Ograniczenie swobody kontraktowej nie zawsze bowiem wyrazone jest expressis verbis w konkretnym przepisie (np.

s. C\%. Zurawska, Wokól..., s. 175 .

60 \%. Radwański, Prawo..., s. 43.

(6) Nakaz ścislej interpretacji pojęcia ustawy jest wynikiem derogacji (ustawą z 28 VIl 1990 r.) pr\%episu art. XVI p.w.k.c., definiującego ustawę jako każdy akt prawa obowiązują$\operatorname{ccg} 0$.

62 Odnośnic do rozróznienia przepisu prawa i normy prawnej zob. S. Wronkowska, 7. Ziembiński, Zarys teorii pańsıwa i prawa, Warszawa 1992, s. 188. 
zakaz sprzedaży części organu własnego ciała wynika z ogółu unormowań dotyczących ochrony dóbr osobistych i regulacji w zakresie legalności zabiegów medycznych). Pewna swoboda interpretacji sprzeciwiająca się identyfikowaniu normy prawnej i przepisu nie powinna jednak być traktowana jako podstawa wprowadzania takich ograniczeń swobody umów, które odwoływalyby się jedynie do ogólnych zasad lub zatożeń systemu prawnego, pozbawionych dostatecznego oparcia normatywnego ${ }^{63}$.

Szeroko ujmowane rozumienie pojęcia sprzeczności z ustawa przy jednoczesnym zaakcentowaniu tego, że stanowi ona najłatwiej uchwytna granice swobody umów, przesądza o pozytywnej ocenie tego kryterium. Nie powinien więc budzić wątpliwości fakt, iż w miarę możliwości sądy będą skłonne powoływać się raczej na ustawę niż odwotywać się do klyteriów inniej precyzyjnych, jakimi sa klauzula general na natury stosunku oraz zasady wspólżycia społecznego.

\section{Zasady wspólżycia spolecznego}

jako wyznacznik granic swobody kontraktowej

Nawiązując do zasad współżycia społecznego ustawodawcá posłużyl sie formulą klauzuli generalnej. $Z$ zasady otwarty i niedookreślony charakter objętych nią pojęć powoduje, że granice przysługującej stronom swobody kontraktowej będa tu znacznie trudniejsze do uchwycenia niż w przypadku odwolania się do imperatywnych przepisów ustawy. Klauzula geneKierunek interpretacji pojeć objętych klauzula zasad wspótżyciach. ecznego ustawodawca powojenny wyznaczył odmiennie niż pod rządam kodeksu zobowiązaí ${ }^{64}$. Na gruncie k.z. dobre obyczaje rozumiano jako nakaz respektowania granic uczciwości i lojalności w prowadzeniu interesów 12 (tzw. zasada słuszności kontraktowej) ${ }^{65}$, bez jakiejkolwiek „otoczki ideologicznej". W okresie powojennym interpretacja natomiast uwzględniać miata pizede wszystkim podstawowe założenia ówczesnego ustroju spolecznopolitycznego. Omawiana klauzula bowiem, w wyniku uzupełnienia jej określenia, iż chodzi o zasady wspólżycia społecznego w PRL (dawna edakcja art. 5 k.c.), nabrała sensu ideologicznego. Poszanowanie tych zasad" nakazywała obywatelom również Konstytucja PRL z 1952 r. (art: 90).

Tak M. Saljan, Zasada..., s. 15.

Klauzula generalną zasad wspólżycia społecznego obcjmowano (jako ,pojęciem zbioiczy'm") przewidziane w art. $55 \mathrm{k} . z$ klauzule dobrych obyczajów i porządku publicznego Zob. orzeczenie SN z 12 XI1 1957 r., OSN 1959, poz. 45.

65. R. Longehamps de Berier, Zobowiqzania, Poznaí 1948, s. 157. 
Obecnie klauzula generalna zasad wspólżycia społecznego występuje na obszarze prawa cywilnego bez jakichkolwiek ograniczeń ideologicznych $^{66}$. Jej nową treść kształtuja - zgodnie z założeniami demokratycznego państwa prawa - respektowane przez nowy porządek wartości, powszechnie uznane w kulturze naszego społeczeństwa i stanowiące zarazem dziedzictwo i składnik kultury europejskiej. W tym kontekście należy więc ujmować wszelkie pojęcia objęte zakresem klauzuli zasad współżycia spotecznego ${ }^{67}$. Nie ma zatem przeszkód, by również wspótcześnic odwolywać się w ramach tych zasad do takich pojęć, jak dobra wiara (w znaczeniu obiektywnym), zwyczaje uczciwego obrotu, sumienność i rzetelność kupiecka, skladające się na pojęcie szeroko ujmowanej shuszności (sprawiedliwości) kontraktowej ${ }^{68}$.

Podobnie jak na gruncie kodeksu zobowiązań, ustawodawca nie wskazat, jak należy rozumieć ograniczenia dotyczące zasad współżycia spolecznego. $Z$ treści art. $353^{\prime} \mathrm{k}$.c. wynika jedynie, iźz respektowanie zasad wspótżycia społecznego ma charakter nakazu - minimum i nie powinno być rozumiane jako pozytywny obowiazek włączenia do treści zobowiązania reguł zawierających określone postulaty słunsznościowe. Strony zawierające umowę musza uregulować treść łączącego je stosunku prawnego w sposób zgodny z przyjettymi i powszechnie akceptowanymi przez spoleczeństwo kryteriami lojalnego i uczciwego postępowania. Celem ustawodawcy nie jest bowiem maksymalizacja wymagań zwiazzanych z przestrzeganiem określonych wartości mieszczących się w zakresie pojęcia zasad wspólżycia spotecznego ${ }^{69}$.

Ustawodawca nje sprecyzowal jednak, kiedy umowa będzie sprzeczna z zasadami wspólżycia spolecznego, co kwalifikowaloby kreowany przez nią stosunek prawny jako wychodzący poza ramy swoboly kontraktowej. Kwestię interpretacji pojęć objętych zakresem zasad wspótzycia spotecznego pozostawiono do rozstrzygnięcia orzecznictwu.

Odwołanie się do judykatury i literatury okresu poprzedzającego zmiany systemowe pozwala na przybliżenie tradycyjnego rozumienia pojęć $z$ art.

${ }^{60}$ Wszelkie dodatki idcologiczne wskazujące kierunek interpretacji objętych klauzula pojęc wraz ze zniana systemu społeczno-politycznego stracily sens i w konsekwencji zostaly formalnie uchylone. Pozostawiono jedynie, socjalistyczun” terminologie, klóra uważ się obecnie w doktrynie za anachroniczną i nieadekwatną do stosunków kontraktowych we wspólczesnym obrocie gospodarczym. Zob. T. Wiśniewski, op.cil., s. 18.

${ }^{67}$ Z. Radwanski, Prawo..., s. 43.

6s ze stanowiskjem tym. zgadza się Sąd Najwyższy, uznając sluszność kontrakıowa za krytcrium ocenne stanowiąe „wskaźnik delimitujący swobodę umów”. Zob. np. orzeczenic 7 sędziów SN z dnia 6 III 1992 r, OSN 1990, poz. 90; uchwala 7 sędziów SN z dnia 20 VII 1993 r., OSN 1993, poz. 208; uchwala 7 sędziów SN z dnia 17 IX 1992 r., OSN 1993, poz. 24.

${ }^{69}$ M. Safjan, Zasada..., s. 15. 
55 k.z. Sięganie do tego wzorca, choć niezbędne ${ }^{70}$, wymaga jednak daleko posuniętej ostrożności. Przy wykładni należy bowien uwzględniać historyczny kontekst wcielenia klauzuli zasad współżycia społecznego w rany kodeksu cywilnego. Jednakże, pomimo iż orzeczenia sprzed okresu transformacji ustrojowej zmierzaty przede wszystkim do ochrony systemu wartości ówczesnego ustroju, sądy siłą rzeczy niejako uwzględniały nurt „prawa shusznościowego" (czyli zasadę sprawiedliwości kontraktowej) ${ }^{7 !}$. Za sprzeczne z zasadami współzycia spotecznego doktryna i orzecznictwo uznały te umowy, w których wyznaczone treści zachowania stron lub cel slosunku zobowiazzaniowego godzily w wartości lub normy postępowania uznane za zasady powszechnie obowiązujące. Byty to więc, co podkreślata juź judykatura przedwojenna, umowy zmierzające do popierania działań niemoralnych i shżące osiaganiu z tych działań korzyści ${ }^{72}$. Na podstawic w ten sposób ustalonego kierunku wykładni za sprzeczne z zasadami wspótżycia spolecznego (a w konsekwencji - nieważne w świetle art. 58 k.c.) Sąd Najwyższy uznat w szczególności tzw. umowy dławiące (kneblujące), które pbejmowały caly majątek dłużnika (obecny i przyszly) w zamian za świadczenia nie pozostające w godziwej proporcji do świadczeń wierzyciela ${ }^{73}$.

Dorobek najnowszego orzecznictwa w zakresie zasad wspótzycia spolecznego na tle art. $353^{1}$ k.c. jest natomiast jeszcze stosunkowo nieduzy". Uznając za sprzeczne z omawiana klauzula postanowienia umowy kredytu bankowego przyznające kredytodawcy uprawnienia do jednostronnej, dowolnej zmiany stawek oprocentowania Sąd Najwyzszy stwierdzit w uzasadnieniu, iż zasady stuszności (wspótżycia) wymagają określenia w unowie kredytu okoliczności, od których spetnienia uzależnione będzie uprawnicnie do dokonanja wspomnianej zmiany ${ }^{75}$. Także i obecnie sądy odwołują się do koncepcji wspomnianych umów kneblujących. Jest to częsta praktyka

${ }^{70}$ Por. W. Czachórski, Zobowiqzania..., s. 115.

${ }^{7} \mathrm{Na}$ przyklad orzeczenie SN z dnia 17 V1 1981 r. (OSP 1983, po\%. 14.9), w którym za spracczne z zasadani wspótzycia uznano zmowę uczestników licylacji w colu umoziliwienia nabycia auta za najnizszq cenç; zob. tez orzeczenic SN z dnia 14 XII 1973 I. (OSP 1974, poz. 161).

72 J. Kolzonek, J. Rosenbluth, Kodeks zobowiqzań. Komentarz, Kraków 1936, s. 142.

${ }^{73}$ Zob. R. Piasceki w: Komentarz do kodeksu cywilnego, Warszawa 1989, teza do art. 58 k.c.

${ }^{74}$ Więcej orzeczćn zapada na llc art. 5 k.c., w klórym jednak omawiana klauzula ma inny zakres zastosowania - stanowi jedynic wyznacznik granic wykonywania prawa poclmiotowego.

${ }^{75}$ Uchwala 7 sędziów SN z dnia 22 V 1991 r., OSNCP 1992, poz. 1 oraz z dnia 6 II $1992 \mathrm{r}$ (nicpublikowane). Stanowisko to potwierdzone zostało w uchwale \% dnia $19 \mathrm{~V} 1992 \mathrm{r}$., OSP 1993, poz. 119, z glosa W. Pyziota oraz w postanowieniu TK z dnia 15 Xil 1992 r., OTK 1992, L. IJ, s. 194. 
w przypadku budzących wątpliwości co do zgodności z zasadani słuszności kontraktowej umów wyłącznych przedstawicielstwa handlowego i kontraktów franchisingowych, ale nie tylko. W uchwale z 17 września 1992 r. $^{76} \mathrm{Saqd}$ Najwyższy za kneblujące (i jako takje sprzeczne z zasadami współżycia społecznego) uznał umowy, które polegaty na jednostronnie narzucanej formie zaspokajania potrzeb ludności w trudno dostepne dobra (chodziło o garaże), przy rażącej nieadekwatności świadczeń wzajemnych ${ }^{77}$.

Odwotanie się $w$ zakresie zasad współżycia spotecznego do reguł uczciwego obrotu, dobrej wiary, rzetelności i lojalności kupieckiej jest powszechnie uznawane $w$ doktrynje i literaturze. Jedyne zastrzeżenia pojawiają się na tle werbalnej formuty omawianego ograniczenia. Pojawiają się bowiem postulaty przywrócenia terminologii, która posłuzył sie ustawodawca przedwojenny w art. 55 k.z. ${ }^{78}$ Ostateczna decyzja w tej kwestii należy jednak do ustawodawcy.

Odwołując się do idei słuszności kontraktowej, należy pamiętać o tym, że objęte tym pojecciem zasady (uczciwości, lojalnego działania ctc.) zakieślają granice swobody kontraktowej zarówno dla obrotu nieprofesjonalnego, jak i profesjonalnego, w tym stosunków umownych z udziałem wytącznie podmiotów zawodowo trudniacych się prowadzeniem dzialalności gospodarezcj. Wiaże się to z potrzeba wyeksponowania odmiennych elementów stuszności w obrębie każdego z nich. W obrocie nieprofesjonalnym wystarczające będzie odwotanie się do zasad dobrej wiary i uczciwości kontraktowej. W przypadku obrotu nieprofesjonalnego natomiast na plan pierwszy wysuna się zasady związane z pojęciem uczciwości i lojalności kupieckiej oraz rzetelności w prowadzeniu interesów. Poza tym przy ocenie należytej staranności trzeba dodatkowo mieć na uwadze zawodowy charakter. dziatalności (art. $355 \$ 2$ k.c.). Ograniczenie swobody umów ze względu na zasady wspótżycia spotecznego ma więc obecnie charakter uniwersalny ${ }^{79}$.

\section{Ograniczenie zasady swobody umów ze względu na wlaściwość (naturę) stosunku prawnego}

Odwotując się do właściwości (natury) stosunku (co stanowi legislacyjne novum. $)^{80}$ ustawodawca po raz pierwszy w sposób wyraźny wskazał,

${ }^{76}$ OSN 1993, po\%. 24.

77 Uchwala 7 sęlziów SN z dnia 17 IX 1992 r, OSN 1993, po\%. 24.

78 Więcj na len temat Z. Radwański, Prawo..., s. 43.

79 .. Wiśnicwski, op.cit., s. 17.

${ }^{80}$ Odniesienie do klauzuli generalnej w postaci natury stosunku znane jest natomiast więks\%ości ustąwodawstw europejskich, gdzie nakaz zgodnego \% naturæ ukszlaltowania treści zobowiqzania odnosi sį̧ jednak przede wszystkin do szczególnego sposobu zawarcia 
ze stosunki zobowiazzaniowe mają swoją naturę, której nie można sprowadzuc do zgodności z treścią ustawy ani z zasadami współżycia społecznego, ale traktować jako w pełni autonomiczny i samodzielny czynnik delimitująWhy zakres swobody umów.

Tt Natura stosunku okazała się tak trudnym do zdefiniowania pojęciem, że Wotychczas nie doczekala się wytyczenia jednolitej wykładni. W nielicznych pracach cywilistycznych, w których poruszano zagadnienie whaściwosci stosunku, oraz na tle niewielkiego jeszcze dorobku orzecznictwa wykształcily się dwa zasadnicze, konkurujące ze sobą kierunki interpretacji onnawianego kryterium.

Zgodnie $z$ pierwszym $z$ nich ograniczenie $w$ postaci natury stosunku można rozumieć szerzej - jako skierowaną do stron dyrektywę respektowania zasadniczych cech (znamion) stosunku zobowiązaniowego, to jest tych jego części, których istnienie decyduje o istocie tworzonego węzła prawnego. O dyrektywie tej należy wnioskować albo bezpośrednio z charakteru stosunków zobowiązaniowych w ogólności, albo z charakteru przynależnego danemu typowi tych stosunków.

W przypadku przyjęcia węższej interpretacji natury stosunku odwołanie się do tego kryterium ozıaczać będzie nakaz przestrzegania przez stro$n y$ pewnych specyficznych, normatywnie sprecyzowanych części składoTwych poszczególnych typów nazwanych stosunków zobowiazaniowych, Których nieuwzględnienie lub zmodyfikowanie spowodowaloby merytoyczne wypaczenie ustawodawczego wzorca stosunku zobowiązaniowego wynikającego $z$ określonego typu umowy ${ }^{81}$.

Waski kierunek interpretacji pojęcia natury stosunku nie zyskał szerszego poparcia w doktrynic i judykaturze. Podnosi się mianowicie to, ze tistawowe typy umów nie wiąża stron przy kształtowaniu stosunków zoboWiazzaniowycli. Naruszenie cech charakterystycznych danego normatywnego typu umowy (essentialia negotii), o ile nie stanowi jednocześnic naruszenia isstawy i zasad współżycia społecznego powoduje, że mamy do czynienia 1. Z Iinnym typem stosunku lub umową nienazwana. W takich wypadkach przy rozstrzyganiu kwestii naruszenia granic swobody kontraktowej wystarczające jest odwołanie siẹ do zasad współżycia społecznego ${ }^{82}$. Eksponuje się

umiowy (ij. z zastosowanicin wzorców) i ma na celu ochronę strony slabszcj (np. $\$ 9$ nieThileckiej Gesetz zur Regelung des Recht der Allgemeinen Geschäftsbedingungen oraz art. 8 Wzivajcarskiej ustawy o zwalczaniu nicuczciwej konkurencji). Odwołanie się do wlaściwości Triosunku jako czynnika delimitującego zakres swobody umów można więc uznać za wyraz Theniclencji do „europeizacji”” polskiego prawa zobowiązań. Zob. E. Traple, Ochrona slabszej Thisony umowy a a kontrola treści unowy ze względu na przekroczenie granic swobody iniów i sposób zawarcia umowy, Kwartalnik Prawa Prywatnego 1997, ni 2, z. 2, s. 232.

81 Ibidem.

${ }^{82}$ Z. Radwaíski, Zobowiqzania..., s. 133-134. 
nadto, iż ujmowane wassko kryterium natury stosunku nie ma calkowicie samodzielnego charakteru, ale petni raczej funkcje porządkujące, stanowiąc jedynie "swoista pomocnicza dyrektywę interpretacyjna umożliwiająca wyodrębnienie w obszarze regulacji dotyczących danego typu tych norm, które ze względu na petnioną dla danego stosunku zasadniczą rolę należatoby potraktować jako ius cogens"

Doktryna i judykatura skłonne są raczej zaakceptować szerszą interpretacje klauzuli natury stosunku, za którą wydaje się przemawiać teoretycznoprawna argumentacja „z natury zobowiązania”. Zakłada ona to, że wobec bezspornego przyjęcia istnienia określonych konstruktywnych cech treściowych stosunku obligacyjnego (właściwych każdej umowie), ułożenie przez strony treści tego stosunku w sposób „wypaczający" te cechy, powoduje naruszenie natury zobowiązania. Problemy pojawić się moga jednak na tle ustalenia (zidentyfikowania) tych cech. Zgodnie z formula nakazująca szeroką interpretacje, o fundamentalnych cechach (elementach) zobowiązania należy wnioskować $z$ "charakteru stosunków zobowiązaniowych w ogólności” albo z charakteru „przynależnego danemu typowi tych stosunków".

Charakter stosunków zobowiązaniowych w ogólności ustalić można, opierając się na podstawowych regulach konstrukcji i funkcjonowania zobowiązań, przy uwzględnieniu spolecznej roli, jaka pełnią w obrocie. Pomocne będą tu normy ogólne prawa zobowiązań (zawarte zwłaszcza pierwszych dziesięciu tytułach księgi III k.c.), wskazujące zasadnicze cechy umów. Opierając się na przedstawionych kryteriach za fundamentalne cechy stosunku obligacyjnego uznać należaloby wobec tego te elementy wy. wnioskowane $z$ charakteru zobowiazań w ogólności, z których wynika, nip względność wykreowanego w drodze zawarcia umowy stosunku prawnego równorzędność stron stosunku obligacyjnego, korelatywne sprzęzenie upra. wnień wierzyciela z obowiązkami dlużnika ${ }^{84}$.

W odniesieniu zaś do danego typu stosunku obligacyjnego nalezy pa miętać, że jest to kategoria szersza, obejmująca poza essentialia negoti także takie elementy kwalifikujące, jak np. świadczenia towarzyszące świad czeniu głównemu, cel gospodarczy umowy, zwyczaj regulujący treść stosun ku (które odnoszą się zarówno do treści, jak i celu zobowiazania). O wy różnieniu określonych typów umowy decyduje nie tylko kodeksowy ukla umów (choć ma on znaczenie podstawowe), ale także tradycja prawniczz poglądy doktryny, orzecznictwo oraz zmiany w systemie spoleczno-gospe darczym. Stąd typy umów, w przeciwieństwie do „ogólnych cech zobowia

83 M. Saljan, Zascada..., s. 16.

84 Tak M. Szczygiet, Wtaściwość (ncriura) stosunku zobowiqzaniowego jako ogranicz. nie zasady swobody umów, Palestra 1997, ni 7-8, s. 17. 
zań" podlegać moga modyfikacji, co trzeba uwzględniać powołując się na kryterium natury określonego typu stosunków obligacyjnych ${ }^{85}$. Tak szerokic ujęcie typu stosunku pozwala wyróżnic pewne typy umów nienazwanych i na tej podstawie ustalić takie fundamentalne cechy danego typu umowy nienazwanej, których brak spowoduje sprzeczność z natura stosunku prawnego $0^{86}$.

Wobec wciaż pojawiających się watpliwości co do treści i zakresu klauzuli natury stosunku, wynikających z ogólnego jedynic sformutowania wylycznych wykładni, zasadne jest odwołanie się do przykładów dostarczanych przez doktrynę i orzecznictwo (stosunkowo jeszcze w tym zakresie nieliczne).

W doktrynie mówi się o sprzeczności z szeroko pojmowana z właściwością stosunku w wypadku uzgodnienia przez strony w umowie należącej do kategorii starannego działania, iż wykonanie zobowiązania polegać będzie na osiagnięciu konkretnego rezultatu (np. przyrzeczenie "wygrania” sprawy klienta w umowie o obstuge prawna obietnica wyleczenia pacjenta w umowie o świadczenie usług medycznych ${ }^{87}$ ). Sprzeczność celu zobowiazania z jego natura następuje natomiast w przypadku umów, w których interes wierzyciela polegałby wylącznie na wpływaniu na życie osobiste i rodzinne dłużnika (np. umowa między małżonkami, w której jedno z nich wyraża zgodę na rozwód bez orzekania o winie w zamian za korzyści przy przyszłym podziale majątku wspóknego). Takiej samej ocenie powinny podlegać także té umowy, w których dłużnik byłby zobowiazzany zadośćuczynić „tego rodzaju zachciance wierzyciela, która nie licowałaby z godnością dlużnika"88.

Konkretnych przykładów sprzeczności z szeroko ujmowaną naturą z,obowiazania dostarcza orzecznictwo. Za najbardziej znaczaca należy uznać uchwate 7 sędziów Sąu Najwyższego z 22 maja 1991 r. (III CZP 55/91) ${ }^{89}$. Sąd stwierdził w niej, iż natura umowy gospodarczej i generowanego przez nia stosunku sprowadza się generalnie do tego, że wyraźa ona i pozwala

${ }^{85}$ T. Guść, op.cit., s. 21.

${ }^{86}$ Nie wszyscy jednak autorzy są zgodni co do moźliwości wyodrębnienia poszczególnych typów umów nienazwanych. Zdaniem M. Safjana, w odniesicniu do wszclkich tego typu stosunków nienazwanych (bez wegrium natury zobowiazania odwolujące się do ogólmoze znalezć zastoso cech stosunku obligacyjnego, bez których jest on pozbawiony prawinej relewancji. Zob. M. Safjan, Umowy..., s. 1.

${ }^{87}$ Tak T: Wiśniewski, op.cit., s. 15; M. Safian, Zasada..., s. 16. Odmiennie M. Szczygieł, op.cit., s. 19. Zdaniem autora omawiane przypadki stanowia przykłady węzszego ujecia klauzuli natury stosunku.

38 J. Guść, op.cit., s. 22.

${ }^{89}$ OSNCP 1922, nr 1, z. 1, s. 6. Znaczenie orzeczenia polegato na lym, ze stalo sie jodną z podstaw, na których oparto definicje i zakres pojęciowy natury stosunku sensu largo. 
realizować interes kazdej ze stron, poniewaź zaś interesy te bywają przeciwslawne, istote umowy stanowi uzgodnienie woli stron, wyrażającej ich interesy. Zgoda obydwu stron jest oczywistym wymogiem tak przy zawarciu umowy, jak i przy zmianach jej treści, stąd też nawet przy najdalej idących ulatwieniach w realizacji inicjatywy zmian pozostawiona jest drugicj stronie moźliwość odmowy zgody na zmiany. W tym stanie rzeczy za sprzeczne z naturą stosunku Sąd Najwyższy uznał pozostawienie w ręku jednej tylko strony możliwości dowolnej zmiany jej warunków ${ }^{90}$. W uzasadnieniu cytowariej uchwały Sąd zaznaczył ponadto, iż sprzeczność z natura pojawia się szczególnie wyraźnie właśnie w przypadku umów zawieranych na podstawie regulaminów (a szerzej - wszelkich typów wzorców). Jest to oczywiste $z$ tego względu, ze profesjonalista zawsze będzie zainteresowany jak najkorzystniejszym dla siebie uksztattowaniu regulacji zawieranych masowo umów.

Orzeczenia w przedmiocie sprzeczności z naturą stosunku zapadały także na tle innych stosunków zobowiazaniowych o charakterze ciąglym, zwiaszcza zaś najmu i dzierzawy. W orzeczeniach z 15 lutego 1996 r.

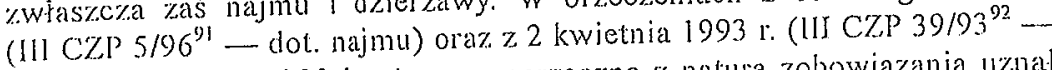
dot. dzierzawy) Sąd Najwyższy za sprzeczne z natura zobowiazania uznał umieszczenie $w$ umowie zawartej na czas oznaczony postanowienia o rozwiazaniu w drodze wypowiedzenia, w przypadku gdy brak wyraźnego umocowania ustawowego. W przypadku najmu oznacza to, iż strony nie moga skutecznie postanowić, że umowa najmu lokalu mieszkalnego zawalta na czas oznaczony może zostać wypowiedziana przed uplywem okresu, na jaki zostala zawarta.

O naruszeniu kryterium whaściwości stosunku rozumianego wąko mozna by natomiast mówić np. w razie zastrzezenia $w$ umowie spótki prawa cywilnego, że wspólnicy nie będa ponosić solidarnej odpowiedzialności za zobowiązania spółki (art. 864 k.c.), w umowie darowizny zaś - w przypadku zastrzezenia o wyłączenju mozliwości odwolan ia darowizny z powodu razacej niewdzięczności obdarowanego (art. 898 k.c.) $)^{93}$.

Sąd Najwyższy potwierdził dopuszczalność węźszej interpretacji klauzuli natury stosunku w uzasadnieniu do orzeczenia z 28 kwietnia $1995 \mathrm{r}$. (III CZP 166/94) $)^{\text {gx }}$, stwierdzając, iż ,interpretacja wąska prowadzi do uznawania za sprzeczne z naturą zobowiazania lakiego znieksztalcenia

90 Sprawa dolyczyla umieszczenia w regulaminie bankowym, dotyczacym warunków prowadzenia rachunku bankowcgo, postanowien uprawniajacych bank do jednostronnej \%miany treści tego regulaminu.

"II OSN 1996, po\% 69.

"2 OSN 1993, po\%. 178.

9 Tak $\%$. Wiśniewski, op.cit., s. 16.

24 OSN 1995, \% 10, po\%. 135. 
umowy typowej, znanej prawu zobowiazzá, które wykracza poza ramy stosunku umownego, akceptowanego w sferze danego ustawodawstwa, gdy jednocześnie nie istnieje podstawa do uznania danego stosunku jako umowy o charakterze mieszanym, któlą strony pragną zawrzeć".

Pomimo pojawiających sie na tle pojecia natury stosunku umownego trudności interpretacyjnych, nie sposób nie docenić roli, jaką klauzula ta pełni na gruncie polskiego prawa zobowiązań. Jak się bowiem zauwata w literaturze, ustanowienie nowego wskaźnika delimitującego zakies swobody umów w tej postaci przyczyniać się będzie do wzmocnienia funkcji ochronnej art. $353^{i}$ k.c. Rozwój stosunków kontraktowych wykraczajacy poza typy ustawowe, w powiazaniu z nowymi, relewantnymi prawnic zjawiskami cywilizacyjnymi (w szczególności w dziedzinie medycyny, biotechnologii, genetyki, informatyki), zagrażać może podstawowym dobrom osobistym konsumentów. Zanim takie niebezpieczne tendencje, wypaczajace treści i cele prawa zobowiązań, zostana zahamowane przez ustawodawce poprzez ustanowienie w danym zakresie regulacji imperatywnej, judykatura może podważać zgodność pewnych klauzul umownych z prawem, z uwagi ha sprzeczność z natura stosunku ${ }^{95}$. Rozwiazanie takie wydaje się stuszne, przede wszystkin ze względu na brak w przepisach prawa cywilnego klauzuli porządku publicznego, na którą można by powotać się w omawianych przypadkach. Stąd często uważa się, że zastępuje ją klauzula natury stosunku ${ }^{96}$.

Klauzula generalna natury stosunku jest zazwyczaj oceniana pozytywnie w piśmiennictwie, a glosy sprzeciwu co do potrzeby waczenia jej w ramy art. $353^{\prime}$ k.c. jako nowego wskaźnika delimitującego zakres swobody umów są stosunkowo nieliczne ${ }^{97}$. Judykatura jednak ciagle jeszcze powoluje się na nią z dużą ostrożnością.

95 J. Guśc, op cit., s. 20.

\% Tak jest m.in. w przypadku eksperymentów medyeznych. Bęąca warunkiem legalności zabiegu zgoda pacjenta moze się okazać in concreio niewystarczajaca. Następujc mu bowiem „ograniczenic autonomii jednostki, wynikạące z ogólnych zasad porządku publicznego". i wobec tego zgoda na działanic, z którym wiąze siç ryzyko w postaci zagrozcnia zdrowia, a nawet zycia nic będzie mieścić się w sferze prawnic dozwoloncj. Celem umowy nie moze być bowiem swiadczenie dóbr osobistych (zdrowia, żcia) polegajace na przynoszeniu jednej ze stron (w zamian za ckonomiczny ckwiwalent) bezpowionego uszczerbek na zdrowiu czy nawel grozace utrata zycia. Tak M. Saljan, Wybrane aspekty prawne eksperymentów medycznych, Suldia luridica 1993, mi 26, s. 73-74.

${ }^{27}$ Np. zdaniem A. Stelmachowskiego (op.cit., s. 97) rols omawianej klau\%uli spclnić moga przepisy k.c. regulujące skutki prawne dokonan ia czynnosei prawnej pozonej, w zakresie, w jakim jest to potrzebne dla ,zapobiènenia sytuacjom unownym, które pod plas\%eczekicm przewidzianych w prawie umów mialyby realizowac zupelnic inne cele. Fe Traple (Ochrona..., s. 233) uwaza natomiasl, iż krytcrium to jest ,zbyl daleko posuniçtym paraso"lem ochronnym" i za wzorem niemieckim powinno być powolywane jedynic ze względu na 


\section{Skutki przekroczenia granic zasady swobody umów}

Artykuł $353^{\prime}$ k.c. należy do kategorii norm bezwzględnie obowiązujących (iuris cogentis). Naruszenie któregokolwiek $z$ wymienionych w przepisie kryteriów swobody kontraktowej uruchamia sankcję nieważności bezwzględnej przewidzianą w art. 58 k.c. i odnosząca się do każdej czynności prawnej spełniającej wymogi objęte hipotezą tej normy. Nieważność dotyczyć może calej umowy lub tylko poszczególnych jej postanowień. W crugim przypadku kontrakt pozostaje w mocy co do pozostałych czesści, chyba że $z$ okoliczności wynika, iż bez postanowień dotkniętych nieważnością umowa w ogóle nie zostałaby zawarta (art. 58 § 3 k.c.).

$Z$ treści art. 58 k.c. wynika jednak, iż obok sankcji nieważności bezwzględnej (lub nawet zamiast niej) pojawić się mogą inne jeszcze skutki. I tak np. niewykluczone jest stwierdzenie nieważności względnej. $Z$ przypadkiem takim będziemy mieć do czynienia przy wyzysku (art. 388 k.c.), gdzie rażące naruszenie ekwiwalentności świadczeń, wynikające $z$ pogwałcenia przez stronę silniejsza zasad przyzwoitego postępowania, stanowi przekroczenie granic $z$ art. $353^{\prime}$ k.c. W literaturze podaje się również za przyklad sankcji odmiennej niż przewidziana $w$ art. 58 k.c. orzeczenie przepadku świadczenia na rzecz Skarbu Państwa (art. 411 k.c.). W przypadku gdy strony przystapily już do wykonania umowy, dodatkowo (obok nieważności bezwzględnej) w grę wejść może w szczególności obowiązek zwrotu świadczenia nienależnego (art. 410 k.c.) ${ }^{98}$. Sąd Najwyższy w uchwale z. 7 kwietnia 1993 r. ${ }^{99}$ uznał, że umowa spólki $z$ 0.o., sprzeczna z przepisami k.h., nie powoduje nieważności unnowy, lecz likwidację spólki.

Przepis art. 58 k.c. nie przewiduje wprost sankcji w przypadku sprzeczności celu i treści umowy $z$ naturą stosunku. Nie ulega jednak wątpliwości, że nieważność bezwzględna (ewentualnie inne skutki prawne) odnosić się będzie również do tego kryterium. Art. $353^{\prime}$ k.c. nie stanowi bowiem w zakresie kryterium natury stosunku modyfikacji sankcji przewidzianej $w$ art. 58 k.c., a jedynie zakreśla pozytywnie granice swobody kontraktowej. O sankcjach jej naruszenia decydować będą zawsze zasady ogólne.

\section{Falstyczne ograniczenia swobody umów}

Ograniczenia swobody kontraktowej wskazane treścią normy kompetencyjnej art. $353^{1}$ k.c. oraz innych przepisów prawa przedmiotowego naka-

potrzcbe ochrony stabszej strony umowy $i$ to tylko w wypadku, gdy jest ona zawierana na podstawie wzorca.

${ }^{98}$ M. Saljan, Swoboda..., s. 19.

'OSN 1993, poz. 172. 
zujących czyynić użytek $z$ przyznanej kompetencji należą do ograniczeń ogólnych. Ustanawiają one bowiem dopuszczalne ramy, w których strony "moga. ksztal tować treść łączącego je stosunku zobowiązaniowego. Praktyka :współczesnego obrotu dowodzi jednak, że istnieje także szereg ograniczeń faktycznych przysługującej kontrahentom swobody. Dotyczą one zarówno ksztallowania treści umów (w przypadku tzw. kontraktów adhezyjnych, zawieranych z udziałem wzorców umownych), jak i swobody decyzji w kwestii zawarcia umowy, co $z$ kolei determinować może osobę kontrahenta (umowy obowiązkowe zawierane w ramach tzw. przymusu kontraktowego).

\section{Umowy zawierane $z$ udziałem wzorców (adhexyjne)}

Możliwość posługiwania się przez profesjonalistów wzorcami umownymi (w postaci ogólnych warunków umów, wzorów umów oraz regulaminów) przyczyniła się do usprawnienia obrotu, stając się jednocześnie nie tyle uwatym, co niezbędnym jego elementem ${ }^{100}$.

$Z$ drugiej jednak strony „standardyzacja” („uniformizacja”) umów doprowadziła do eliminacji indywidualnych negocjacji stron w fazie przedkontraktowej. Slabsza strona umowy - nabywający towary lub usługi na własny użytek indywidualny odbiorca świadczeń (konsument) pozbawiony zostaje realnego wpływu na treść stosunku zobowiązaniowego ${ }^{101}$. Gwarantowana normą art. $353^{1}$ k.c. swoboda umów sensu siricto nabiera w takiej sytuacji charakteru formalnego, a umowa zawierana na podstawie wzorca przyjmuje postać adhexyjnej (przystapienia) ${ }^{102}$. Treść umowy zostaje „narzucona" przez stronę silniejszą stronie słabszej (konsumentowi) albo częściowo (np. w umowie przewozu koleja indywidualnemu uzgodnieniu podlegać będzie cel podróży, data odjazdu, powrotu etc.), albo w całości (do akceptacji en bloc, np. w zakresie przewozu komunikacją miejska). W ostatnim przypadku odrzucenie warunków proponowanych przez proferenta oznaczać będzie rezygnacje z zawarcia umowy. Konsumentowi pozostaje więc jedynie swoboda decyzji w zakresie zawarcia bądź niezawarcia umowy (co nie zawsze będzie rozwiązaniem korzystnym, zwłaszcza wówczas, gdy

\footnotetext{
${ }^{100}$ P. Atiyah, An Introdtction to the Law of Contracts, Oxford 1995, s. 15.

101 Nic stanowi natomiast ograniczenia swobody kontraktowej wzorcotwórcza dzialatność proferenta. Przeciwnie, tworzenie wzorców i posługiwanie się nimi jest przcjawem swobody ksztaltowania treści stosunków zobowiązaniowych i wyboru formy, w jakiej umoyva ma być zawarta. W literaturze podkreśla sic̨ nawet, ze istnienie wzorców jest „šczytowym wykwitem" zasady swobody umów. Tak E. Lętowska, Prawo umów konsumenckich, Warszawa 1999, s. 235.

102 Więcej na temat ewolucji i koncepcji umów adhezyjnych zob. E. Lętowska, Wzorce umowne. Ogólne warınki umów, wzory i regulaminy, Warszawa-Wroclaw 1975, s. 23 in.
} 
przedmiotem świadczenia jest dobro powszechnie poszukiwane i niezbędne jako zaspokajające podstawowe potrzeby jednostki). Natomiast w przypadku objęcia wzorcem części postanowień umowy, zakres swobody przysługiwać będzie konsumentowi w zakresie accidenlalia negotii, np. przy zawieraniu umowy kredytowej indywidualnie uzgadniany jest terminu splaty kredytu, wysokość poszczególnych rat, rodzaj zabezpieczenia ${ }^{103}$,

Należy jednak zauważyć, że z istnienia wzorca w zakresie określonego rodzaju (kategorii) umów nie wynika nakaz bezwzględnego stosowania go w każdej sytuacji. Praktyka wskazuje, że pojawiać się moga odstępstwa na "zecz indywidualnych pertraktacji kontrahentów, nakierowane na odmienne niż nakazane treścia wzorca rozlożenie wzajemnych praw j obowiazków. Przykładem jest spotykana w praktyce dzialalności banków instytucja określana jako tzw. privale banking. Polega ona na tym, ze w stosunku do określonej kategorii klienteli (tzw. VIP-ów), bank nie stosuje wzorca (np. regulaminu umowy rachunku bankowego), a treść umowy jest indywidualnie negocjowana przez strony (np. umowy o wyższe depozyty terminowe) ${ }^{101}$. Praktyka taka pojawiła się również w zakresie dzialainości zakładów ubezpieczeniowych. Reguta jednak pozostaje zawieranic umów na podstawie postanowień zawartych we wzorcli.

Wzorce umowne narzucać moga równiez określone obowiazki co do sposobu zawarcia umowy. Jeżeli z postanowień wzorca wynikać będzie nakaz zawarcia tımowy w określonej formie, strona będzie ograniczona takize i w tym zakresie.

Poglad, iz tworzenie i stosowanie przez profesjonalistów wzorców stanowi faktyczne ograniczenie ("wypaczenie") swobody kontraktowej ich kontrahentów w zakresie kształtowania treści stosunków obligacyjnych, jest ugruntowany w doktrynie ${ }^{105}$. Nie wzbudza wątpliwości kwestia wzo1ców normatywnych, których mozliwość wydawania przewidziana jest wytącznie na podstawie delegacji ustawowej zawartej w art. $555^{1}$ k.c. ${ }^{106}$, jako wyjątek od nienormatywnego, co do zasady, charakteru wzorców. Pojawity sie jednak opinie, iż w świetle art. $353^{\prime}$ k.c. wzorce nienormatywne wzmac-

103 Ibidem.

Ion Zob. M. 13ączyk w: Prawo praedsiebiorshw, Warszawa 1999, s. 34.

105 Zob. W: Czachórski, Zobowiqzania..., s. 110.

106 Artykut $555^{\prime}$ został dodany ustawą z dnia 21112000 r, o ochronie nicktórych praw konsumcritów oraz o odpowicdzialności za szodę wylządzona przez produkt niebezpieczny, (D\%.U. Nr 22, poz. 271). Wydanc na podstawic zawartcj w nim delegacji rozporzadzenic Rady Ministrow do określenia szczególowych warunków zawierania i wykonywania umów sprzedazy między przedsiçbiorcami i konsumentami ma zastąpic rozporzalzenic z $30 \mathrm{~V}$ $1995 \mathrm{r}$. (przewidziane $w$ art. $384 \mathrm{w}$ dawnym brzmieniu), które $z$ dnicm 30 VI $2002 \mathrm{r}$ s(rac moc (niezalcznie od tego, czy będzie ju\% nowe rozporządzenie). Zob. E. Lętowska, Ustawa o ochronie niektórych praw konsumentów. Komentarz, Warszawa 2000, s. 141-142. 
niają zasadę swobody unów. Kontrahent musi bowiem każdorazowo zgodzić się na treść wzorca, jeżeli zawarte w nim postanowienia maja być dla niego wiążące $w^{\prime}$ konkretnej umowie (wiązanie vi consensu) ${ }^{107}$.

\section{Umowy obowiązkowe jako faktyczne ograniczenie autonomii kontraktowej}

Podczas gdy zawieranie umów na podstawie wzorców pozbawia podmiot autonomii w zakresie kształtowania treści stosunku zobowiązaniowego, w przypadku kontraktów obowiązowych ograniczeniu ulega swoboda decyzji co do zawarcia bądź niezawarcia umowy.

Istnienie umów obowiązkowych jest konsekwencja pojawienia się na gruncie prawa zobowiązań tzw. przymusu koxtraktowego. Polega on na. cia wskazanej norma umowy, w przewidzianych przepisami okoliczno-
sciach i przy spełnieniu określonych przestanek. Przystugująca temu podhinotowi swoboda decyzji zostaje ograniczona w ten sposób, że nie może on nie przyjąc skierowanej do niego oferty, a w przypadku nieuzasadnionej odmowy zawarcia umowy objętej przymusem kontraktowym, jak równiez uchylania sie od obowiazku kontraktowego, odpowiednie przepisy przewidują określone sankcje natury cywilnoprawnej ${ }^{108}$, a w niektórych przypadThach nawet administracyjnoprawnej ${ }^{109}$.

O przymusie kontraktowym w prawie polskim, a co się z tym wiaże, o. unowach obowiazzkowych, możenny mówić przede wszystkim wodniesie7niu do przewoźnika publicznego w komunikacji tzw. regularnej (otwartej) ${ }^{110}$ oraz zakładów energetycznych i wodociaggowo-kanalizacyjnych w zakresie Whswiadczonych ustug polegajacych na dostarczaniu gazu, energii cieplnej Trelektrycznej oraz wody i odprowadzania ścieków ${ }^{11 !}$. Uzasaduienia objęcia Wumow zawieranych przez wymienione podmioty przymusem kontraktowym Wháleży upatrywać w koncepcji service publique. Zakłada ona, iż dobra i usługi

Ty 107 Tak. W. Katner, Ogólne warnnki unów, wzory umów i regulaminy w świelle noweli\$racji kodeksu cywilnego z $1990 \mathrm{r}$, [w:] Rozprawy z polskiego i europejskiego prana prytoalnego. Księga pamiąikowa ofiarowana profesorowi J. Siapskiemu, Kraków 1994, s. 154. H. 108 Np. art. 30 ust. 2 ustawy Prawo energetyczne z 10 IV 1997 :. (Dz.U. Nr 54, poz. 348) Hijpewiduje możliwość ustalenia przez Sad Antymonopolowy treści oświadczenia woli na Tpodstawie art. 64 k.c.

$709 \mathrm{~Np}$. w postaci kary pieniezznej określonej wysokosici, prowidrianej w art. 56 ust. I jkit 4 prawa energelycznego.

H. 110 Więcej na ten temat zob.: W. Górski, Prawo transportowe, Szczocin-Ziciona Góma 1998 , s. $47 . \mathrm{in}$.

Hy ili M. Nesterowicz, Czy można zaniechać doslarczania wody, Wodociłgi Polskie, wl'zcsień 1997, \$. 21. 
mieszczące się w ramach użyteczności publicznej stanowią podstawę bytowania społeczeństwa i jego aktywności (w tym gospodarczej) w poszczególnych dziedzinach życia i ze względu na tę specyficzną ceche powinny być dostępne zawsze, tj. w sposób nieprzerwany, w wysokiej jakości i po przystępnych cenach. Na dalszy plan schodzi natomiast indywidualny interes gospodarczy podmiotu świadczącego wspomniane usługi. Podporządkowanie to natomiast stanowi podstawę uprawnienia ustawodawcy do nałożenia na określone podmioty obowiazku zawarcia umowy z odbiorcami ushug ${ }^{12}$.

Umowy obowiązkowe istnieją również na gruncie prawa ubezpieczeń gospodarczych w ramach tzw. ubezpieczeń obowiazkowych. Obciążający zakład ubezpieczeń przymus kontraktowy nie jest jednak w tym wypadku uzasadniany formułą użyteczności publicznej, ale wiąże się z szeroko pojętą funkcją ochronną instytucji ubezpieczeń (potrzeba wzmożonej ochrony w zakresie ryzyk niosacych zwiększone prawdopodobieństwo wystapienia szkody, np. pożar, wypadek komunikacyjny) i ma charakter dwustronny ${ }^{113}$.

Obowiązek zawarcia umowy wynika $z$ ustaw szczególnycl odnoszących do każdego $z$ wymienionych podmiotów zobowiazzanych. Będą to odpowiednio przepisy prawa przewozowego ${ }^{114}$, energetycznego oraz prawa ubezpieczeń gospodarczych ${ }^{115}$. Przymus kontraktowy po stronie zakladów wodociągowo-kanalizacyjnych wyplywa pośrednio z przepisów tzw. prawa wodnego ${ }^{116}$ (obejmującego ustawę i szereg wydanych na jej podstawie aktów wykonawczych). Dużą rolę odgrywaja w tej materii także uregulowania izw. ustawy samorządowej dotyczące obowiązków gmin w zakresie zadań wlasnych ${ }^{117}$.

Umowy obowiązkowe są niewatpliwie odstępstwem od przyjętej na gruncie prawa zobowiązań zasady swobody umów. Ograniczenie autonomii stron ma jednak swoje logiczne uzasadnienie (we wspomnianej koncepcji service publique) oraz podstawy prawne (ustawy szczególne dotyczące określonych typów świadczeń, np. prawo przewozowe, energetyczne). Potrzeba wprowadzenia do systemu prawa instytucji umów obowiązkowych wydaje się więc w pelni uzasadniona i jako taka nie powinna budzić zastrzeżeń.

113 Zob. tez. W. Marek w: L. Lętowska, Obywatel - przedsiębiorstwo. Zagadnienia prawne śviadczeń na rzecz konsumenta, Warszawa-Wroclaw 1982, s. 334 in.

113 por. E. Kowalewski, Prawo ubezpieczeń gospodarczych. Ewolucja i kierunki przemian, Bydgoszcz 1992, s. 46 i $\mathrm{n}$.

114 Zob. art. 2 i 3 ustawy z dnia 15 XI 1984 l. - Prawo przewozowe, tekst jedn. Dz.U. Nr 119, poz. 575:

115 Z.ob. art. 5 ust. 5 ustawy z 28 VII $1990 \mathrm{r}$ o dzialalności ubezpieczeniowej, tekst jedn. Dz.U. z 1996 : Ni 96, poz. 62.

116 Ustawa z $24 \times 1974$ r. Prawo wodne, tekst jedn. Dz.U. z 1.996 r. Ni 106, poz. 496.

117 Zob. alt. 6-10 ustawy z 8 III 1990 r. o samorządzie terytorialnym, Dz.U. z 1990 i. Ni 16, poz. 95. 